\title{
Effects of Allicin and Lycopene on Performance, Carcass, Hematological Profile and Antioxidant Status of Growing Rabbits Through Summer Season
}

\author{
H. S. Zeweil, S. M. Zahran, M. H. Ahmed, Y. El- El-Gindy and W. G. M. \\ Shaglouf \\ Department of Animal and Fish Production, Faculty of Agriculture (Saba Basha), \\ Alexandria University.
}

\begin{abstract}
Forty-five growing V-line rabbits of both sexes, 5 weeks old, were used for the study through summer season from July to September. The rabbits were randomly allocated to five treatments groups of 9 rabbits each. Each treatment was further sub-divided into 3 replicate of 3 rabbits. Group one fed control diet free of feed additives and served as a control. Group 2 and 3 supplemented with 100 and $200 \mathrm{mg}$ allicin / $\mathrm{kg}$ diet. Group 4 and 5 supplemented with 100 and 200 $\mathrm{mg}$ lycopene / kg diet, respectively. Results showed that the groups fed allicin $200 \mathrm{mg} / \mathrm{kg}$ and lycopene $100 \mathrm{mg} / \mathrm{kg}$ in their diets recorded the best $(P \leq 0.05)$ significant average daily weight gain as compared with the control group. The other experimental groups were numerically best in comparison with the control group. Significant improvement in feed conversion ratio was recorded in all experimental groups in comparison with control. Carcass traits and hematological parameters were insignificantly affected by different treatments. All feed additives used in the present study significantly increased antibody titters against $\mathrm{SRBC}_{\mathrm{s}}$ compared with control group at 7, 14 and 21 days after vaccination. Serum total lipids was significantly $(P \leq 0.05)$ decreased due to addition of different feed additives, except with $200 \mathrm{mg}$ allicin in the diet serum total lipids was equal to the control group. Blood serum total cholesterol and triglycerides were significantly $(P \leq 0.05)$ reduced by feeding diets containing different levels of allicin or lycopene in comparison with the control group. The results showed that low density lipoprotein was numerically decreased, however, high density lipoprotein and HDL/LDL ratio were numerically increased due to inclusion different feed additives in the diets. Exposing growing rabbits to high temperature conditions during summer season resulted in elevated $(P \leq 0.05)$ serum MDA, while serum total antioxidant capacity was decreased as presented in the control group, however, supplementation of allicin and lycopene appeared to antagonize the effect of high temperature. In conclusion, rabbit dietary supplementation with allicin or lycopene could have beneficial effects on performance under summer environment without any side effects.
\end{abstract}

Key words: Allicin, lycopene, rabbits, performance, blood lipid profile, blood serum

\section{INTRODUCTION}

Large number of feed additives are available for inclusion in animal and poultry diets to improve animal performance. However, the use of chemical products especially antibiotics, may cause unfavorable side effects. Moreover, there is evidence indicating that some products could be considered as pollutants for human which threaten health on the long-run. Attempts to use the natural materials such as medical plants could be widely accepted as feed additives to improve the efficiency of feed utilization and animal productive performance (Zeweil et al., 2013). Lycopene (LP) is an aliphatic hydrocarbon, a bright red pigment, which is a naturally present carotenoid in fruits and vegetables. Tomatoes are known to be the major source of LP with the content of 3100-8600 $\mu \mathrm{g}$ per $100 \mathrm{~g}$ of tomatoes or their products (Stahl and Sies 1996). The most well-known 
biological effects of LP intake are acting as antioxidant or hypocholesterolemic agent (Di Mascio et al., 1989). It has been known that the hypocholesterolemic or triglyceride-lowering effect of LP is attributed to inhibition of de novo cholesterol synthesis and lipogenesis (Chung et al., 2012; Palozza et al., 2012). Indeed, Fuhrman et al. (1997) proved that LP suppressed the cholesterol synthesis from acetate by $73 \%$ using the macrophage cell line, and confirmed in vitro observation in healthy males in vivo that the concentration of plasma low-density lipoprotein (LDL) cholesterol was reduced by $14 \%$ by LP intake for 3 months. Allicin is an organosulfur compound obtained from garlic, a species in the family Alliaceae (Eric, 1985). Allicin has a distinctively pungent smell and exhibits antibacterial, antifungal, anti-inflammatory and antioxidant properties (Lindsey et al., 2005). Allicin has been found to lower serum and liver cholesterol (Qureshi et al., 1983), inhibit bacterial growth (Cavallito et al., 1994) and reduce oxidative stress (Lindsey et al., 2005 and Choudhary, 2008). Also allicin has immune-stimulatory effect (Cho et al., 2006). The objective of this study is to investigate the effect of feeding allicin and lycopene in two different doses on performance, carcass traits, hematological, blood serum lipid profile and antioxidant status of growing rabbits through Egyptian summer season.

\section{MATERIALS AND METHODS}

Forty-five growing $\mathrm{V}$-line rabbits of both sexes, 5 weeks old, with initial weights of $791.7 \pm 14.1 \mathrm{~g}$ were used for the study. The rabbits were randomly allocated to five treatments groups of 9 rabbits each. Each treatment was further sub-divided into 3 replicate of 3 rabbits. Rabbits were housed in wire floor batteries of $45 \times 36 \times 36 \mathrm{~cm}$ and were offered diets for duration of the feeding trial until reaching 15 weeks of age through summer season from July to September. All animals were kept under similar hygienic conditions. Rabbits were housed in well ventilated block building. Fresh air circulated in the house using exhaust fans. The rabbits were kept within a cycle of $16 \mathrm{~h}$ light and $8 \mathrm{~h}$ dark. Five pelleted diets were prepared. Group one fed control diet free of feed additives and served as a control group. Group 2 and 3 contained 100 and $200 \mathrm{mg}$ allicin (Double Ok Life Co., LtdFujian China "Mainland") / kg diet. Group 4 and 5 contained 100 and $200 \mathrm{mg}$ lycopene (Roche, Levent-Istanbul) / kg diet, respectively. Each group of rabbits was fed one of five experimental diets. Fresh water was automatically available at all times through stainless steel nipples for each cage. The experimental diets were offered to rabbits ad libitum. The formula of basal experimental diet is presented in Table (1) that formulated to cover the requirements of rabbits according to NRC (1977). Individual body weight and feed consumption were recorded weekly. Body weight gain and feed conversion ratio were also calculated. The incidence of dangerous diseases was largely avoided and rabbits have never been treated with any kind of systematic vaccination or medication. At the end of the feeding trial, 3 rabbits were selected from each treatment group randomly, starved of food but not water for 12 hours and slaughtered for carcass analysis. Before slaughtering, $6 \mathrm{ml}$ of blood sample was taken from the ear vein with a sterile syringe. $3 \mathrm{ml}$ of the 
blood was put into a bijon bottle containing ethylene diamine tetracetic acid (EDTA) as an anticoagulant for haematological assay. The remaining $3 \mathrm{ml}$ of the blood sample was put into a sterile vacutainer tube without an anticoagulant for serum biochemical analysis. The haematological assay was carried out to determine erythrocyte indices such as packed cell volume (PCV), and haemoglobin $(\mathrm{Hb})$ values. Red blood cell (RBC) counts were counted on an AO Bright line hemocytometer using a light microscope at 400X magnification after diluting blood samples 200 times with a physiological saline $(0.9 \% \mathrm{NaCl}$ solution) before counting (Natt and Herrick, 1952). White blood cell (WBC) were counted on an AO Bright line hemocytometer using a light microscope at 100X magnification after diluting blood samples 20 times with a diluting fluid (1\% acetic acid solution with a little of Leishman's stain) before counting (Hepler, 1966). Total lipids, triglycerides, cholesterol, low density lipoprotein (LDL) and high density lipoprotein (HDL), concentrations in serum were estimated using commercial kits (Bio Merieux, France) according to the procedure outlined by the manufacturer.

Table(1). Composition and chemical analyses of the basal experimental diet.

\begin{tabular}{lc}
\hline \multicolumn{1}{c}{ Ingredients } & $\%$ \\
\hline Yellow corn & \\
Wheat bran & 19.0 \\
Barley & 11.0 \\
Berseem hay & 17.2 \\
Soybean meal (44\%) & 33.0 \\
Molasses & 15.0 \\
Di-calcium phosphate & 3.0 \\
L-lysine & 1.0 \\
DI-Methionine & 0.1 \\
Premix & 0.1 \\
Salt & 0.3 \\
\hline \multicolumn{1}{c}{ Total } & 0.3 \\
\hline Chemical analyses: & 100 \\
Dry matter (DM), \% & \\
Crude protein\% & 91.36 \\
Ether extract\% & 17.24 \\
Crude fiber\% & 3.26 \\
Nitrogen free extract\% & 12.58 \\
Ash\% & 50.47 \\
Organic matter (OM), \% & 7.57 \\
DE (kcal/kg DM) & 92.42 \\
\hline
\end{tabular}

${ }^{1}$ Vit+Min mixture provides per kilogram contains: Vit A $6000 \mathrm{IU}$; Vit $D_{3} 450 \mathrm{IU}$; Vit E 40 mg; Vit $K_{3} 1 \mathrm{mg}$; Vit $B_{1} 1$ mg; Vit $B_{2} 3 \mathrm{mg}$; Vit $B_{3} 180 \mathrm{mg}$; Vit $B_{6} 39 \mathrm{mg}$; Vit $B_{12} 2.5 \mathrm{mg}$; Pantothenic acid $10 \mathrm{mg}$; biotin $10 \mathrm{mg}$; folic acid $2.5 \mathrm{mg}$; choline chloride $1200 \mathrm{mg}$; Manganese $15 \mathrm{mg}$; Zinc $35 \mathrm{mg}$; Iron 38 mg; Copper $5 \mathrm{mg}$; Selenium $0.1 \mathrm{mg}$; lodine $0.2 \mathrm{mg}$; Selenium $0.05 \mathrm{mg}$. ${ }^{2}$ Analyzed values according to AOAC (1995). DE calculated according to Fekete and Gippert (1986) as: DE (kcal/kg DM) = 4253 - 32.6(Crude fibre \% DM) - 144.4(ash\% DM). 
Three rabbits of each treatment were immunized with $0.1 \mathrm{ml}$ of a $2.5 \%$ Sheep Red Blood Cells (SRBCs) via the marginal ear vein at 15 days after starting the dietary treatment supplementation, to measure Antibody titer against Sheep Red Blood Cells.

The dosage of SRBC for inoculation was pre-determined by a separate trial. Antiserum to SRBCs was collected 7, 14 and 21 days post challenge. One $\mathrm{ml}$ of blood without any anticoagulant was refrigerated to allow red blood cells to settle. If sedimentation was not complete, samples were centrifuged for 1 to $2 \mathrm{~min}$ at 3000 rpm to separate serum and erythrocytes, and the supernatant was collected. Briefly, 96-well plates were first filled with $25 \mu \mathrm{l}$ of physiological saline solution in each well. Then $25 \mu$ of antiserum was pipetted into the first well in duplicates after which $25 \mu \mathrm{l}$ from the first well was pipetted into the second well, and so forth using an automatic pipette. Finally, a $0.75 \%$ of SRBC solution was added to each well. Plates were incubated at $37^{\circ} \mathrm{C}$ for 3 hours and then examined visually for agglutination Wegmann and Smithies, (1966). The agglutination titer was expressed as the $\log ^{2}$ of the reciprocal of the highest serum dilution giving complete agglutination (Nelson et al., 1995). The results were expressed as the mean \pm SEM. All data were analyzed using one way analysis of variance (ANOVA) using SPSS 11.0 statistical software (SPSS, Inc., Chicago, II, 2001). Significant differences between means were detected using new Duncan multiple range test (Duncan, 1955).

\section{RESULTS AND DISCUSSIONS}

Results concerning the effect of dietary supplementation of allicin and lycopene on performance of growing V-line rabbits are illustrated in Table 2. It was observed that there were no significant differences in initial body weight among different treatments showing the random distribution of the experimental rabbits among treatments.

The results illustrated in Tables 2 showed that dietary allicin and lycopene supplementation did not significantly influence the final live body weight of the Vline growing rabbits. But in general it was noted that all the experimental groups including different levels of allicin and lycopene showed numerical increase in final live body weight in comparison with the control one. The obtained results showed that the groups fed allicin $200 \mathrm{mg} / \mathrm{kg}$ and lycopene $100 \mathrm{mg} / \mathrm{kg}$ in their diets recorded the best $(P \leq 0.05)$ significant average daily weight gain. As compared with the control group. These groups surpassed the control one by 8.2 and $7.6 \%$, respectively. 
Table (2). Effect of allicin and lycopene on performance of growing V-line rabbits

\begin{tabular}{lccccc}
\hline & & \multicolumn{2}{c}{ Allicin } & \multicolumn{2}{c}{ Lycopene } \\
\cline { 3 - 6 } Characteristics & Control & $\begin{array}{c}\mathbf{1 0 0} \mathbf{~ m g / k g} \\
\text { diet }\end{array}$ & $\begin{array}{c}\mathbf{2 0 0} \mathbf{~ m g / k g} \\
\text { diet }\end{array}$ & $\begin{array}{c}\mathbf{1 0 0} \mathbf{~ m g / k g} \\
\text { diet }\end{array}$ & $\begin{array}{c}\mathbf{2 0 0} \mathbf{~ m g / k g} \\
\text { diet }\end{array}$ \\
\hline & & & & & \\
Initial body weight, g & $775.6 \pm 31.5$ & $761.2 \pm 27.5$ & $704.4 \pm 29.3$ & $755.0 \pm 26.7$ & $793.3 \pm 23.5$ \\
Final body weight, g & $2380.0 \pm 24.9$ & $2424.4 \pm 42.1$ & $2440.0 \pm 28.4$ & $2482.2 \pm 25.4$ & $2468.1 \pm 33.3$ \\
Daily weight gain, g & $22.92 \pm 0.52^{\mathrm{b}}$ & $23.76 \pm 0.36^{\mathrm{ab}}$ & $24.79 \pm 0.47^{\mathrm{a}}$ & $24.67 \pm 0.34^{\mathrm{a}}$ & $23.93 \pm 0.30^{\mathrm{ab}}$ \\
Daily feed intake, g & $87.1 \pm 0.6$ & $82.7 \pm 0.7$ & $83.0 \pm 1.7$ & $85.0 \pm 1.9$ & $83.3 \pm 1.7$ \\
Feed conversion ratio & $3.82 \pm 0.09^{\mathrm{a}}$ & $3.49 \pm 0.07^{\mathrm{b}}$ & $3.36 \pm 0.09^{\mathrm{b}}$ & $3.45 \pm 0.09^{\mathrm{b}}$ & $3.49 \pm 0.11^{\mathrm{b}}$
\end{tabular}

Different letters (a-b) within a raw denote significant differences between treatments $(\mathrm{P} \leq 0.05)$

Feed intake was insignificantly affected by the difference treatments. Jain et al. (1999) reported that live weight and feed intake were not affected by lycopene supplementation in rat diets. Significant improvement in feed conversion ratio reached to $8.6,12.0,9.7$ and $8.6 \%$ for the rabbits fed diets supplemented with 100 and $200 \mathrm{mg}$ allicin and 100 and $200 \mathrm{mg}$ lycopene in comparison with the control group, respectively. The results suggested by Onyimonyi et al. (2012) found that broilers fed garlic essential oil at a level of $100 \mathrm{mg} / \mathrm{Kg}$ improved feed conversion ratio. The possible explanation for this positive growth promoting effect could be attributed to allicin, an organosulfur compound contained in garlic that promotes the performances of the intestinal flora there by enhance digestion (Pourali et al., 2010). Ramakrishna et al. (2003) showed that garlic supplementation enhances the activity of pancreatic enzymes and provides an environment for better absorption of nutrients. Also, Stanaćev et al. (2011) demonstrated that the chicks fed diets with garlic have achieved better feed conversion ratio since it reduced by $10 \%$, while the birds maintained good health status in comparison with the control group. On the other hand, Aji et al. (2011) reported that administration of $100 \mathrm{mg}$ of garlic resulted in improved body weight gain of broiler chicks, without change in feed conversion ratio.

The results in Table 3 showed that the different treatments had insignificant effect on all carcass traits at 15 weeks of age. Hossian et al. (2015) reported that there was no significant $(P \leq 0.05)$ differences in carcass traits of rabbits fed control group and rabbits fed diets containing 0.25 and $0.50 \%$ dried garlic. 
Table (3). Effect of allicin and lycopene on carcass traits of growing V-line rabbits at 15 weeks of age

\begin{tabular}{lccccc}
\hline & & \multicolumn{2}{c}{ Allicin } & \multicolumn{2}{c}{ Lycopene } \\
\cline { 3 - 6 } Characteristics & Control & $\begin{array}{c}\mathbf{1 0 0} \mathbf{~ m g / k g} \\
\text { diet }\end{array}$ & $\begin{array}{c}\mathbf{2 0 0} \mathbf{~ m g} / \mathbf{k g} \\
\text { diet }\end{array}$ & $\begin{array}{c}\mathbf{1 0 0} \mathbf{~ m g} / \mathbf{k g} \\
\text { diet }\end{array}$ & $\begin{array}{c}\mathbf{2 0 0} \mathbf{~ m g} / \mathbf{k g} \\
\text { die }\end{array}$ \\
\hline & & & & & \\
Pre-slaughter weight, & $2353.3 \pm 73.8$ & $2266.7 \pm 33.8$ & $2365.0 \pm 16.0$ & $2416.7 \pm 26.8$ & $2405.0 \pm 58.9$ \\
Cold carcass,\% & $52.5 \pm 2.5$ & $53.6 \pm 1.3$ & $55.9 \pm 3.4$ & $53.2 \pm 0.3$ & $53.5 \pm 1.0$ \\
Total edible parts,\% & $60.5 \pm 2.0$ & $58.1 \pm 0.9$ & $64.9 \pm 4.6$ & $59.0 \pm 0.7$ & $60.4 \pm 0.4$ \\
Non-edible & $39.5 \pm 2.0$ & $41.9 \pm 0.9$ & $35.0 \pm 4.6$ & $41.0 \pm 0.7$ & $39.6 \pm 0.4$ \\
Parts,\%Head,\% & $5.2 \pm 0.2$ & $5.7 \pm 0.2$ & $5.6 \pm 0.2$ & $5.9 \pm 0.2$ & $4.9 \pm 0.3$ \\
Fur, \% & $13.7 \pm 0.6^{\text {ab }}$ & $13.1 \pm 0.4^{\text {abc }}$ & $11.7 \pm 0.2^{\mathrm{c}}$ & $14.5 \pm 0.8^{\mathrm{a}}$ & $12.5 \pm 0.6^{\mathrm{bc}}$ \\
Liver, \% & $2.59 \pm 0.26$ & $2.80 \pm 0.32$ & $2.33 \pm 0.15$ & $3.09 \pm 0.32$ & $2.61 \pm 0.23$ \\
Heart, \% & $0.34 \pm 0.05$ & $0.28 \pm 0.03$ & $0.31 \pm 0.02$ & $0.32 \pm 0.04$ & $0.35 \pm 0.04$ \\
Kidney, \% & $0.47 \pm 0.00$ & $0.49 \pm 0.04$ & $0.53 \pm 0.06$ & $0.57 \pm 0.05$ & $0.51 \pm 0.01$ \\
Kidney fat,\% & $0.20 \pm 0.05$ & $0.18 \pm 0.06$ & $0.18 \pm 0.04$ & $0.18 \pm 0.05$ & $0.18 \pm 0.06$ \\
Giblets, \% & $3.40 \pm 0.26$ & $3.56 \pm 0.25$ & $3.17 \pm 0.18$ & $3.98 \pm 0.24$ & $3.47 \pm 0.20$ \\
Lungs, \% & $0.50 \pm 0.07$ & $0.67 \pm 0.08$ & $0.55 \pm 0.02$ & $0.65 \pm 0.07$ & $0.54 \pm 0.01$ \\
Spleen\% & $0.06 \pm 0.01$ & $0.05 \pm 0.01$ & $0.07 \pm 0.01$ & $0.07 \pm 0.01$ & $0.06 \pm 0.01$ \\
\end{tabular}

Different letters (a-c) within a raw denote significant differences between treatments $(P \leq 0.05)$.

The findings of Fadlalla et al. (2010), using broilers reported a nonsignificant effect on broiler dressing percentage values, but numerically higher, due to the inclusion of garlic powder. El Azab et al. (2012) reported that all carcass traits did not find any significant difference between the different groups of rabbits fed diets containing 0, 5 and 10\% tomato pomace as a source of lycopene for 8 weeks, except lungs weight.

Results presented in Table 4 showed that the average values of hematological parameters were within the normal range without any significant differences among treatments and the control group, indicating that all tested feed additives had no adverse effects on blood components. Results of Ademola et al. (2009) reported that the red blood cells and hemoglobin concentration of broiler chickens were not affected by dietary garlic. Abd El-Latif et al. (2013) reported that addition of garlic essential oils to broiler diets did not significantly affect RBCs count and it was similar to those of the control group. The RBCs, PCV and Hb values were nearly similar among the control and treatment groups and also fall within the normal range of $3.7-8.0 \times 10^{6}, 25-50 \%$ and $8.9-17.5 \mathrm{mg} / \mathrm{dl}$ reported for healthy rabbits by Mitruka and Rawnsley (1977). The normal PCV indicates the absence of normocytic anaemia which only detected by a decreased number of RBCs or PCV (Coles, 1986). The normal hemoglobin concentration for all the experimental rabbits is probably an indication that different levels of allicin and lycopene used in the present study supported hemoglobin synthesis, which according to Sirosis (1995) is among other factors, primarily affected by protein intake. Njidda et al. (2006) reported that normal range of values for $\mathrm{Hb}$ indicated that the vital physiological relationship of hemoglobin with oxygen in the transport 
of gases (oxygen and carbon dioxide) to and from the tissues of the body has been maintained and was normal. The WBCs counts are used as indicator of stress response and are sensitive biomarkers crucial to immune functions (Graczyk et al., 2003). In the present study, WBCs values were not significantly affected by the dietary treatments as compared with control group. However, the WBCs counts fell within the normal physiological range reported by Mitruka and Rawnsley (1977). This indicates that body defense system of the rabbits in all the treatment groups was not negatively affected by different levels of allicin or lycopene used in the present study. High WBCs counts are usually associated with microbial infection or the presence of foreign body or antigen in the system (Ogbuewu et al., 2010). The comparable mean WBCs counts in all the treatment groups in this study ruled out the possibility of microbial infection.

Antibody titters against SRBCs determined are shown in Table (4) as affected by allicin and lycopene. The results indicated that all feed additives used in the present study significantly increased antibody titters against SRBCs compared with control group at 7, 14 and 21 days after vaccination. The use of different feed additives used in the present study played a role in increasing immune response against some diseases. It is shown that allicin and lycopene were an immunomodulatory. It stimulated humoral immune response of growing rabbits in comparison with the control group.

Table 5 represents the results of the effects of allicin and lycopene on rabbit's serum total lipids, triglycerides, total cholesterol, LDL and HDL concentrations. Results indicated that serum total lipids was significantly $(P \leq 0.01)$ decreased due to addition of different feed additives, except with $200 \mathrm{mg}$ allicin in the diet serum total lipids was equal to the control group. Blood serum total cholesterol and triglycerides were significantly $(P \leq 0.05)$ reduced by feeding diets containing different levels of allicin or lycopene in comparison with the control group. The results showed that low density lipoprotein was numerically decreased; however, high density lipoprotein and HDL/LDL ratio were numerically increased due to inclusion different feed additives in the diets. It was noticed that lycopene was more pronounced on these traits than allicin. Cholesterol is one of the cell and tissue components and is used as a starting material for synthesis of numerous compounds. The animal body utilizes both dietary and endogenous cholesterol. The endogenous part can be converted into bile acids and steroid hormones, while the exogenous portion undergoes intestinal emulsification by bile acids. Roussel et al. (1982) reported that circulating cholesterol level is known to be influenced by the activity of steroid producing organs. Rao and Shen (2002) showed a decrease in blood plasma cholesterol as a result of dietary lycopene supplementation. Sahin et al. (2006) described an increase in the blood plasma HDL concentration of Japanese quail and a significant decrease in the LDL concentration because of lycopene addition. Oshima et al. (1997) reported that human LDL could be protected against photosensitized oxidative damage by lycopene. Paran and Engelhard (2001) reported that lycopene supplementation reduced blood lipids, 
lipoproteins and oxidative stress markers in hypertensive patients. Tocopherols and tocotrienols in dried tomato pomace lowers serum cholesterol by suppressing the posttranscriptional action of 3-hydroxy-3-methylglutaryl coenzyme A (HMG$\mathrm{CoA}$ ) reductase, the rate -limiting enzyme in the mevalonate pathway of endogenous cholesterol synthesis by the liver (Song-Hae et al., 1999). The literature concerning cholesterol lowering by bioactive phytochemicals often concludes that the excretion of bile acid and cholesterol and the resulting depletion of the enterohepatic bile acid pool are important mechanisms of cholesterollowering. The physiological observations are supported by changes in expression of genes regulating bile acid and cholesterol metabolism. Enhanced excretion of bile acid, cholesterol and total fat were observed in dried tomato seed supplemented diet and the related genes expressions were also modulated (Shao et al., 2013). There is a linear relationship between enzyme activity and CYP7A1 gene expression (Bartley et al., 2010), so the observed up-regulation of CYP7A1 likely indicates bile acid synthesis was increased although the bioactive component is not known. Although the expression of HMGCoA reductase (3-hydroxy- 3methylglutaryl CoA reductase) was not determined, the reduction of hepatic cholesterol and up-regulations of gene CYP51 and CYP7A1 would suggest that the expression of HMGCoA would also be increased.

It is generally accepted that dietary garlic supplementation inhibits the hepatic activities of lipogenic and cholestrogenic enzymes in pigs (Qureshi et al., 1987) and rats (Mathew et al., 2004). Similarly, significant reductions in blood plasma concentrations of triglycerides were observed in broilers (Al-Homidan, 2005) in response to feeding garlic-supplemented diets compared with control birds. The present results are in accordance also with the findings obtained by Prasad et al. (2009), who found that blood plasma total cholesterol; triglycerides, low density lipoprotein and very low density lipoprotein were significantly decreased, while high density lipoprotein was significantly increased by garlic supplementation in broiler chickens in comparison to the control group.In addition, Choi et al. (2010) indicated that dietary garlic powder significantly decreased total and low-density lipoprotein cholesterol and increased high-density lipoprotein cholesterol in broiler blood. Mirhadi et al. (1992), reported allicin that present in garlic, significantly inhibited hypercholesterolemia, reduced tissue cholesterol, lowered low density lipoprotein concentration (LDL) and raised high density lipoprotein concentration (HDL). This may probably be due to the possible mechanism of hypocholesterolaemic and hypolipidemic action of garlic products which depresses the hepatic activities of lipogenic and cholesterogenic enzymes such as malic enzyme, fatty acid synthase, glucose-6-phosphatase dehydrogenase (Chi et al., 1982; Qureshi et al., 1983a) and 3-hydroxyl-3-methyl-glutaryl-CoA (HMG-CoA) reductase (Qureshi et al., 1983b, 1987). Afzal et al. (1985) reported that polyunsaturated fatty acids prevent atherosclerosis through the formation of cholesterol esters. They further reported the presence of higher polyunsaturated fatty acids like arachidonate and eicosapentenoate in garlic which could well be responsible for preventing atherosclerosis. Furthermore, garlic powder can 
facilitate activity of enzymes which are involved in the conversion of cholesterol to bilious acids and subsequently, there will be less cholesterol in the carcass (Bordia et al., 1975; Raeesi et al., 2010).

Exposing growing rabbits to high temperature conditions during summer season resulted in significant decrease $(P \leq 0.05)$ in serum total antioxidant capacity which was obtained in the control group, however, supplementation of allicin and lycopene appeared to antagonize the effect of high temperature. The different levels of allicin (100 and $200 \mathrm{mg}$ ) and lycopene (100 and $200 \mathrm{mg}$ ) increased total antioxidant capacity in blood serum to rich an increase their value by $75.3,43.2,51.9$ and $49.4 \%$, respectively, in comparison with the control group. Heat stress causes increased free radical production (Halliwell and Gutteridge, 1989) and lowers the concentrations of antioxidant vitamins and minerals such as E, C, A and $\mathrm{Zn}$ in serum and tissues (Sahin and Kucuk, 2003). Free radicals trigger the metabolic disorder, cell death and growth retardation (Okada, 1996).

Malondiaidehyde (MDA) used as a marker of the oxidative stress. Exposing growing rabbits to high temperature through summer season resulted in elevated $(P \leq 0.05)$ serum MDA as presented in the control group, however, supplementation of allicin and lycopene appeared to antagonize this effect. The mean concentration of malondialdehyde (MDA) level was significantly $(P \leq 0.05)$ lower in the group given $100 \mathrm{mg} / \mathrm{kg}$ dietallicin containing diet (13.07), followed by those group had $200 \mathrm{mg}$ allicin containing diet (14.37), then lycopene 100 and 200 $\mathrm{mg}$ fed groups (15.0 and 15.57, respectively) without significant differences between the last two groups. The control group recorded the highest value of MDA (17.57). Therefore, the obtained results showed that 100 and $200 \mathrm{mg} / \mathrm{kg}$ dietallicin and 100 and $200 \mathrm{mg}$ lycopene resulted in lowering blood serum MDA in descending order by 25.6, 18.2, 14.6 and $11.4 \%$, respectively, in comparison with the control group. Generally it was observed that the low levels of allicin and lycopene was more effective in decreasing blood serum lipid peroxidation in comparison with the high levels. These results were in disagreement with those presented by Farag (2014) who showed that the lowest MDA value was obtained from the highest levels of lycopene and of allicin (300 mg/ kg diet). Also, the obtained results indicated that allicin was more superior in comparison with lycopene fed groups.

Phytochemicals present in aged garlic extract are believed to act in synergistic way and they exert their antioxidant activity by promoting scavenging of reactive oxygen species by means of enhancing the cellular antioxidant enzyme superoxide dismutase, catalase, glutathione peroxidase, and increase the level of glutathione in cells and some of the important defense mechanism in living cells. Some of the potential benefits of aged garlic extract include decreasing the cardiovascular diseases by suppressing/inhibiting lipid peroxidation and oxidation of LDL (Amagase et al., 2001 The overall effect of the garlic compounds would perhaps be to prevent or reduce injuries through oxidative stress and free radicals. 
Lycopene, a major carotenoid present in tomatoes, is one of the most potent antioxidants among the dietary carotenoids. Antioxidant properties of lycopene are thought to be responsible primarily for its biological effects, which may be important in the prevention of chronic diseases associated with oxidative stress such as cancer and cardiovascular diseases. Studies have provided evidence in support for the protective role of lycopene in chronic diseases (Rao and Shen, 2002). Lycopene is the most potent singlet oxygen quencher natural carotenoid (Rao and Agarwal, 1999; DiMascio et al., 1989; Nguyen and Schwartz, 1999; Agarwal and Rao, 2000). Lycopene was reported to inactivate hydrogen peroxide and nitrogen dioxide (Bohm et al., 1995). Agarwal and Rao (1998) have shown that blood lycopene levels increased by dietary lycopene supplementation. Also, Jain et al. (1999) reported that dietary lycopene increased serum and liver lycopene and thiols levels and decreased serum TBARS (14\% reduction) concentration in rats. This supports the findings of Rao and Agarwal (1998) which showed that dietary lycopene protected lipid, protein and DNA from oxidation. The protective action of lycopene on MDA confirms previously reported findings of other investigators (Rao and Agarwal, 1999; Rao and Shen, 2002; Jain et al. 1999). Leal et al. (1999) reported that the broilers exposed to lycopene showed a reduction in MDA production. Paran and Engelhard (2001) reported that lycopene supplementation reduced oxidative stress markers such as homocysteine in hypertensive patients. However, an inverse association between MDA and antioxidant vitamins has been mentioned by others (Halliwell and Gutteridge, 1989).

\section{Table (4). Effect of allicin and lycopene on hematological parameters and sheep RBCs rabbits}

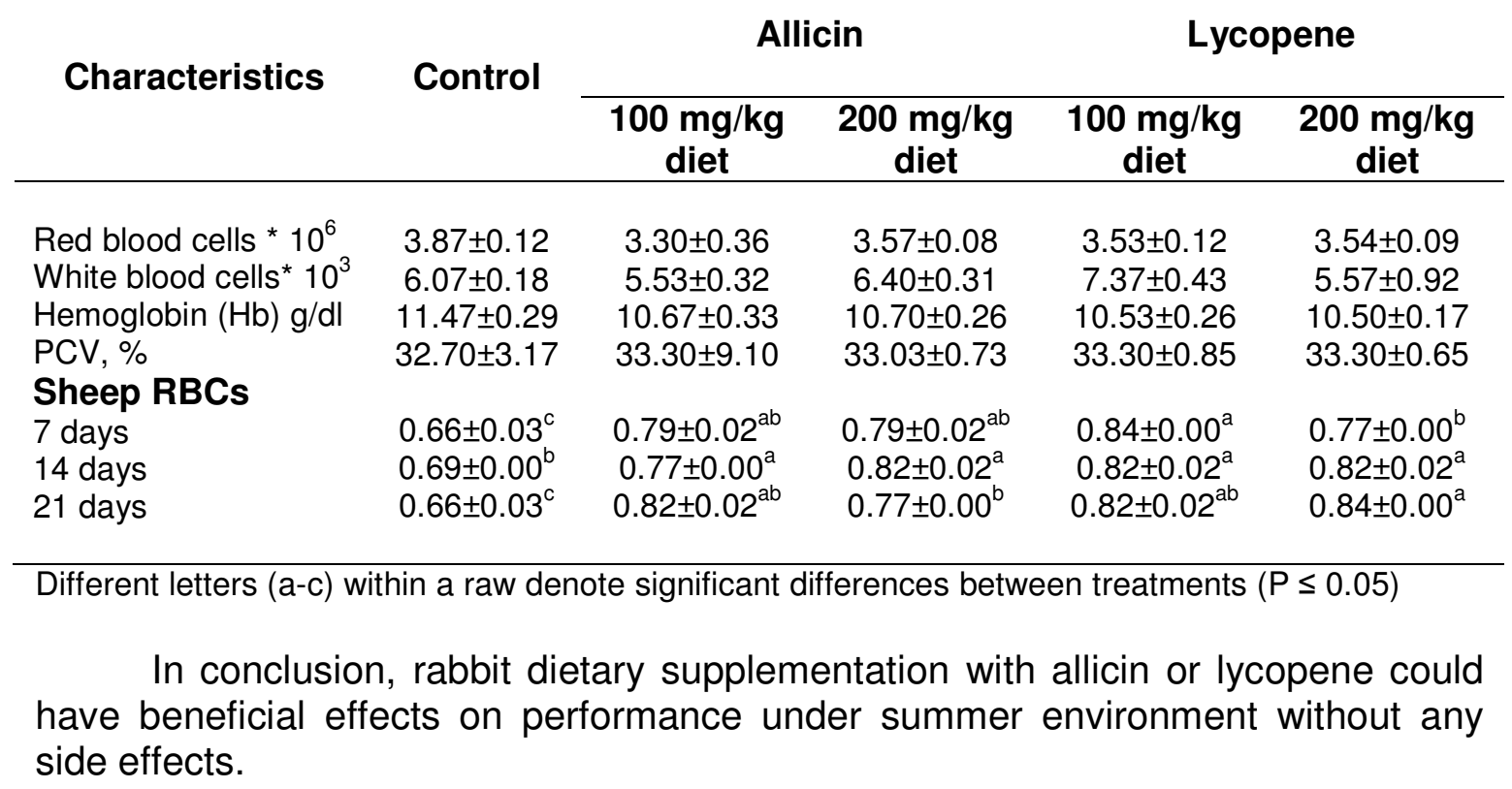


J. Adv. Agric. Res. (Fac. Agric. Saba Basha)

Table (5). Effect of allicin and lycopene on blood serum lipid profile of growing V-line rabbits at 15 weeks of age

\begin{tabular}{|c|c|c|c|c|c|}
\hline \multirow[b]{2}{*}{ Characteristics } & \multirow[b]{2}{*}{ Control } & \multicolumn{2}{|c|}{ Allicin } & \multicolumn{2}{|c|}{ Lycopene } \\
\hline & & $\begin{array}{c}100 \mathrm{mg} / \mathrm{kg} \\
\text { diet }\end{array}$ & $\begin{array}{c}200 \mathrm{mg} / \mathbf{k g} \\
\text { diet }\end{array}$ & $\begin{array}{c}100 \mathrm{mg} / \mathrm{kg} \\
\text { diet }\end{array}$ & $\begin{array}{c}200 \mathrm{mg} / \mathrm{kg} \\
\text { diet }\end{array}$ \\
\hline Total lipids, mg/dl & $310.67 \pm 7.22^{a}$ & $264.00 \pm 1.73^{b}$ & $320.00 \pm 2.65^{\mathrm{a}}$ & $226.67 \pm 4.06^{\mathrm{c}}$ & $230.00 \pm 2.89^{c}$ \\
\hline Triglycerides, mg/dl & $76.33 \pm 1.33^{\mathrm{a}}$ & $63.70 \pm 1.10^{c}$ & $70.10 \pm 0.95^{b}$ & $63.97 \pm 0.80^{\circ}$ & $71.20 \pm 0.52^{b}$ \\
\hline Cholesterol, mg/dl & $97.40 \pm 1.22^{\mathrm{a}}$ & $87.63 \pm 1.48^{\mathrm{c}}$ & $93.00 \pm 1.15^{b}$ & $70.53 \pm 0.86^{d}$ & $61.90 \pm 0.46^{\mathrm{e}}$ \\
\hline $\mathrm{HDL}, \mathrm{mg} / \mathrm{dl}$ & $48.67 \pm 0.67$ & $49.67 \pm 0.33$ & $50.00 \pm 0.58$ & $50.33 \pm 0.88$ & $50.67 \pm 0.67$ \\
\hline LDL, mg/dl & $47.00 \pm 1.15$ & $45.33 \pm 1.45$ & $46.87 \pm 2.44$ & $43.33 \pm 1.20$ & $43.67 \pm 2.03$ \\
\hline HDL/LDL ratio & $1.04 \pm 0.02$ & $1.10 \pm 0.04$ & $1.07 \pm 0.05$ & $1.16 \pm 0.03$ & $1.17 \pm 0.05$ \\
\hline $\mathrm{TAC}, \mathrm{mmol} / \mathrm{l}$ & $0.81 \pm 0.06^{\mathrm{C}}$ & $1.42 \pm 0.08^{\mathrm{a}}$ & $1.16 \pm 0.07^{b}$ & $1.23 \pm 0.06^{\mathrm{ab}}$ & $1.21 \pm 0.05^{\mathrm{ab}}$ \\
\hline $\mathrm{MDA}, \mathrm{nmol} / \mathrm{ml}$ & $17.57 \pm .23^{\mathrm{a}}$ & $13.07 \pm .15^{\mathrm{d}}$ & $14.37 \pm .07^{c}$ & $15.00 \pm .25^{\mathrm{b}}$ & $15.57 \pm .19^{b}$ \\
\hline
\end{tabular}

\section{REFERENCES}

A.O.A.C. (1995). Official methods of Analysis $16^{\text {th }}$ Edition Association of official Analytical chemists. Washington D.C.

Abd El-Latif, S.A., N. S. Saleh., T.S. Allam and E. W. Ghazy (2013). The Effects of Rosemary (Rosemarinus afficinalis) and Garlic (Allium sativum) Essential Oils on Performance, Hematological, Biochemical and Immunological parameters of Broiler Chickens British Journal of Poultry Sciences 2 (2): 1624.

Ademola ,S.G., G.O. Farinu and G. M. Babatunde (2009). Serum lipid growth and haematological parameters of broilers fed garlic, ginger and their mixture. World Journal of Agricultural Sciences. 5(1): 99-104.

Afzal, M., R.A.H. Hassan, A.A. El-kazini and R.M.A. Fattah (1985).Allium sativum in the control of atherosclerosis.Agric. Biol. Chem., 49; 1187-1188.

Agarwal S. and A.V. Rao (2000). Tomato lycopene and its role in human health and chronic diseases. CMAJ., 163:739-744.

Agarwal, S. and A. V. Rao (1998). Tomato lycopene and low density lipoprotein oxidation: a human dietary intervention study. Lipids 33:981-984

Aji, S. B., Ignatuius, K., Ado, A.Y., Nuhu, J.B., and Abdulkarim, A. (2011). Effect of feeding onion (Allium cepa) and garlic (Allium sativum) on some performance characteristics of broiler chickens. Research journal of poultry science 4: $22-27$

AL-Homidan, A. A. (2005). Efficacy of using different sources and levels of allium cepa, allium sativum and zingiber ofjicinale on broiler chick's performance.Saudi Journal of Biological Sciences. 12 (2): 96- 102.

Amagase H., B.L. Petesch, H. Matsuura, S. Kasuga and Y. Itakura (2001). Intake of garlic and its bioactive components. J. Nutr. 131:955S-962S. 
Bartley, R., J.P. Corfield, A.A. Hawdon, B.N. Abbott, S.N. Wilkinson and B. Nelson (2010). Impacts of improved grazing land management on sediment yields, Part I:hillslope processes. Journal of Hydrology, 389: 237-248.

Bohm, F., J.H. Trinkler and T.G Truscott (1995). Carotenoids protect against cell membrane damage by nitrogen dioxide radical. Nat. Med. 1, 98-99.

Bordia, A., H.C. Bansal, S.K. Arora and S.V. Singal (1975).Effect of the essential oils of garlic and onion on dementary hyperlipemia.Atherosclerosis, 2; 1518.

Cavallito, C.J., Buck, J.S. and Suter, C.M. (1994). Allicin, the antibacterial principle of Allium sativum. Determina-tion of the chemical composition. Journal of the Ameri-can Chemical Society, 60, 1952-1958.

Chi, M. S., E. T. Koh and T. J. Stewart (1982). Effect of garlic on lipid metabolism in rats fed cholesterol or lard. J Nutr , 112:241-248.

Choi, I. H., W.Y. Park and Y.J. Kim (2010). Effects of dietary garlic powder and alpha-tocopherol supplementation on performance, serum cholesterol levels, and meat quality of chicken. Poultry Science 89 , 1724-1731.

Choudhrry, R. (2008). Benificial effect of Allium sativum and Allium tuberosumon experimental hyperlipidemia and atherosclerosis. Pak. J. Physiol. 4, 7-9.

Chung, J., K. Koo, F. Lian, K. Q. Hu, H. Ernst and X. D. Wang (2012). Apo-10'lycopenoic acid, a lycopene metabolite, increases sirtuin 1 mRNA and protein levels and decreases hepatic fat accumulation in ob/ob mice. J Nutr 142:405-410

Chung, L.Y. (2006). The Antioxidant Properties of Garlic Compounds: Allyl Cysteine, Alliin, Allicin, and Allyl Disulfide. Journal of medicine Food J Med Food, 9, (2), 205-213

Coles, E.H. (1986). Veterinary Clinical Pathology (4th edition). W.B Saunders Co., Philadelphia. pp.10-79.

Di Mascio, P., S. Kaiser and H. Sies (1989). Lycopene as the most efficient biological carotenoid singlet oxygen quencher. Arch Biochem Biophys 274:532-538

Duncan, D. B. (1955). Multiple range and F., test Biometric. 11:42.

El-Azab, M. A. I. (2012). Utilization of tomato pomace in feeding rabbits. M. Sc. Thesis, Fac. Agric. (Saba Basha), Alexandria University, Egypt.

Eric, B. (1985). "The chemistry of garlic and onions". Scientific American 252(March): $\quad$ 114-9. doi:10.1038/scientificamerican0385114. PMID 3975593.

Fadlalla, I. M. T., B. H. Mohammed and A. O. Bakhiet (2010). Effect of feeding garlic on the performance and immunity of broilers. Asian Journal of Poultry Science, 4: 182-189.

Farag, M. E. E. (2014). Effect of supplementation of some extracts of phytochemicals on the productive performance and carcass traits for Gimmizah chickens strain. Ph. D thesis, Fac. Agric. (Saba Basha), Alexandria University, Egypt.

Fekete S., Gippert T. (1986). Digestibility and nutritive value of nineteen important rabbit feedstuffs. J. Applied Rabbit Res., 9: 103-108. 
Fuhrman, B., A. Elis and M. Aviram (1997). Hypochoesterolemic effect of lycopene and $\beta$-carotene is related to suppression of cholesterol synthesis and augmentation of LDL receptor activity in macrophages. Biochem Biophys Res Commun 233:658-662

Graczyk, S., A. Pliszczak-Krol, B. Kotonski, K. J. Willze and Z. Chmielak (2003). Examination of haematological and metabolic changes mechanisms of acute stress in Turkeys. Electronic Journal Polish Agriculture and University Veterinary Medicine 6:1-10.

Halliwell, B.E., and J. M. C. Gutteridge (1989). Lipid peroxidation: a radical chain reaction. In: Free Radicals in Biology and Medicine, 2nd ed. Oxford University Press, New York, NY, pp. 188-218.

Hepler, O. E. (1966). Manual of Clinical Laboratory Methods. Thomas Spring Field. Illinois.

Hossian, J., M. Kamruzzaman, A. Akbar and A. Haque (2015). Feeding garlic powder on growth performance, nutrient digestibility and carcass characteristics of rabbit. International Journal of Natural and Social Sciences 2(5): 74-81.

Jain, C.K., S. Agarwal and A.V. Rao (1999). The effect of dietary lycopene on bioavailability, tissue distribution, in-vivo antioxidant properties and colonic preneoplasia in rats. Nutr. Res., 19:1383-1391.

Leal, M., A. Shimada, F. Ruiz and E. G. de Mejia (1999). Effect of lycopene on lipid peroxidation and glutathione-dependent enzymes induced by T-2 toxin in vivo. Toxicol Lett 109:1-10

Lindsey, F., J. Macpherson and H. Bernhard (2005). "The pungency of garlic : Activation of TR PA1 and TRPV1 in response to allicin]". Current Biology 15 (10): 929-934.

Mathew, B. C., N. V. Prasad and R. Prabodh (2004). Cholesterol-lowering effect of organo-sulphur compounds: a possible mechanism of action. Kathmandu University Med. J. 2 (2): 100-102.

Mirhadi, S. A., S. Singh and P. P. Gupta (1992). Effect of garlic supplementation to cholesterol-rich diet on development of atherosclerosis in rabbits. Indian Journal of Experimental Biology, 29(2): 162-168.

Mitruka, B.M. and H. M. Rawnsley (1977). Clinical biochemical and hematological reference values in normal experimental animals. Masson Publ. Co. New York, pp. 102-117.

Nelson, N.A., N. Lakshmanan and S. J. Lamont (1995). Sheep red blood cell and Brucella abortus antibody responses in chickens selected for multitrait immunocompetence. Poultry Sci., 74:1603-1609.

Nguyen, M.L. and S.J. Schwartz (1999). Lycopene: chemical and biological properties. Food Technol, 53:38-45.

Njidda, A. A., J. U. Igwebuike and C. E. Isidahomen (2006). Haematological Parameters and carcass characteristics of weaning rabbits fed grade levels of molasses.Global Journal of Agric. Sci., 5(7): 167-172.

Ogbuewu, I.P., M. C. Uchegbu, I. C. Okoli and M. U. Iloeje (2010). Assessment of blood chemistry, weight gain and linear body measurements of pre- 
puberal buck rabbits fed different levels of neem (Azadirachta indica A. Juss.) leaf meals. Chilean Journal of Agricultural Research 70(3):515 - 520.

Okada, S. (1996). Iron-induced tissue damage and cancer: the role of reactive oxygen species-free radicals. Pathology International, 46: 311-332.

Onyimonyi, A.E., P.C. Chukwuma and C. Igbokwe (2012).Growth and hypocholesterolemic properties of dry garlic powder (Allium sativum) on broilers. Afr. J. Biotechnol., 11(11): 2666-2671.

Oshima, S., H. Sakamoto, Y. Ishiguro and J. Terao (1997). Accumulation and clearance of capsanthin in blood plasma after the ingestion of paprika juice in men. J. Nutr. 127, 1475-1479.

Palozza P, Catalano A, Simone RE, Mele MC, Cittadini A (2012). Effect of lycopene and tomato products on cholesterol metabolism. Ann Nutr Metab 61:126-134

Paran E. and Y. Engelhard (2001). Effect of tomato's lycopene on blood pressure, serum lıpoproteıns, plasma homocysteıne and oxıdatıve sress markers in grade I hypertensıve patıents. AJH-,14:333-336.

Pourali, M., S. A. Mirghelenj and D. Kermanshashi (2010). Effect of garlic powder on productive performance and immune response of broiler chickens challenged with Newcastle disease virus. Global Veterinaria, 4:616-621.

Pourali, M.; S.A. Mirghelenj and H. Kermanshahi (2010). Effects of garlic powder on productive performance and immune response of broiler chickens challenged with Newcastle Disease Virus. Global Vet., 4:616-616.

Prasad, R.; M.K. Rose.; M. Virmani.; S.L. Garg and J.P. Purl (2009). Lipid Profile of Chicken (Gallus domesticus) in Response to Dietary Supplementation of Garlic (Allium sativurn). International Journal of Poultry Science 8: 270-276.

Qureshi, A. A., T. D. Crenshaw, N. Abuirmeileh, D. M. Peterson and C. E. Elson, (1987).Influence of minor plant constituents on porcine hepatic lipid metabolism: impact on serum lipid. Atherosclerosis, 64: 109-115.

Qureshi, A. A.; Abuirmeileh, N.; Din, Z.Z.; Ahmad, Y.; Burger, W.C. and C. E Elson,.(1983b). Suppression of cholesterogenesis and reduction of LDL cholesterol by dietary ginseng and its fractions in chicken liver .Atherosclerosis, Volume 48, Issue1, July 1983, Pages 81-94.

Qureshi, A.A., Abuirmeileh, N., Din, Z.Z., Elson, C.E. and W.C. Burger, (1983a). Inhibition of cholesterol and fatty acid biosynthesis in liver enzymes and chicken hepatocytes by polar fractions of garlic. Lipids, 18, 343- 348. doi:10.1007/BF02537229

Qureshi, A.A., N. Abuirmeileh, Z. Din, C.E. Elson and W.C. Burger (1983). Inhibition of cholesterol and fatty acid biosynth esis in liver enzymes and chicken hepatocytes by polar fractions of garlic. Lipids, 18, 343- 348.

Raeesi, M., S.A. Hoeini-Aliabad, A. Roofchaee, A. Zare Shahneh and S. Pirali (2010). Effect of periodically use of garlic (allium sativum) power on performance and carcass characteristics in droiler chickens. World Academy of Science, Engine.Techno. 68; 1213-1219. 
Ramakrishna, R. R., K. Platel and K. Srinivasan (2003). In vitro influence of spices and spice-active principles on digestive enzymes of rat pancreas and small intestine. Nahrung 47: 408- 412.

Rao, A.V. and H. Shen (2002). Effect of low dose lycopene intake on lycopene bioavailability and oxidative stress. Nutrition Research, 22: 1125-1131.

Rao, A.V. and S. Agarwal (1998). Bioavailability and in vivo antioxidant properties of lycopene from tomato products and their possible role in the prevention of cancer. Nutr. Cancer 31, 199-203.

Rao, A.V. and S. Agarwal (1999). Role of lycopene as antioxidant carotenoid in the prevention of chronic diseases: a review. Nutr. Res.,19:305-323.

Roussel, J.D., T.J. Aranas and S.H. Seybt, (1982). Metabolic profile testing in Holstein cattle in Louisiana: Reference values. Am. J. Vet. Res., 43: 16581660.

Sahin, K. and O. Kucuk ( 2003). Heat stress and dietary vitamin supplementation of poultry diets. Nutr. Abstr. Rev. Ser. B Livest. Feed Feeding 73, 41R-50R.

Sahin, K.; M. Onderci.; N. Sahin.; M.F. Gursu and O. Kucuk (2006). Effects of lycopene supplementation on antioxidant status, oxidative stress, performance and carcass characteristics in heat-stressed Japanese quail. Journal of Thermal Biology, 32:307-312.

Shao, D., G. E. Bartle, W. Yokoyama, Z. Pan, H. Zhang and A. Zhang (2013). Plasma and hepatic cholesterol-lowering effects of tomato pomace, tomato seed oil and defatted tomato seed in hamsters fed with high-fat diets. Food Chemistry, Vol. 139: 589-596.

Sirosis, M. (1995). Veterinary clinical laboratory procedure. Mosby year book, Inc. St. Louis, Missouri, USA.

Song-Hae, B.; L.Sung-Hehi.; P. Yong-Bok.; B. Ki-Hwan.; S. Kwang-Hee.; J. Tae-Sook and C. Myung-Sook (1999). Plasma and hepatic cholesterol and hepatic activities of 3-hydroxy-3-methyl-glutaryl-CoA reductase and Acyl CoA: Cholesterol transferases are lower in rats fed citrus peel extract or mixture of citrus bioflavonoids.J.Nutr.,129:1182-1185.

SPSS Statistical Packages for th e Social Sciences, (2001). Statiatical software for windows version 11.0 Microsoft. SPSS ${ }^{\circledR}$, Chicago, IL, USA.

Stahl, W. and H. Sies (1996). Lycopene: A biologically important carotenoid for humans? Arch. Biochem. Biophys. 336, 1-9.

Wegmann, T.G. and O. Smithies (1966). A simple hemagglutination system requiring small amount of red cells and antibodies. Transfusion, 6: 67-73.

Zeweil, H. S., M. Mahmoud, Y. Eid, M. Abd El-Rahman and M. El-Saied (2013). Effect of supplementation of some extract of photochemical on the productive performance and carcass traits for Gimmizah chickens strain. $16^{\text {th }}$ European Symposium Poultry Nutrition 26-29 August 2013, Potsdam, Germany. 


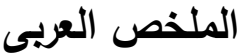

\section{تأثيرات اللأليسين والليكوبين على معدل الأداء ، الأبيحة ، والصفاث الهيماتولوجية للام والحالة الضد تأكسدية للأرانب النامية خلال فصل الصيف}

\section{حسن زويل ، سليمان زهران ، محمد حسن ، ياسمين الجندى ، وليد شقلوف} قسم الانتاج الحيوانى والسمكى - كلية الزراعة - سابا باشا - جامعة الاسكندرية

أستخدم 0 ؛ أرنب من سلالة V-line من كلا الجنسين عمر خمسة أسابيع خلال موسم الصيف من شهر يوليه الى

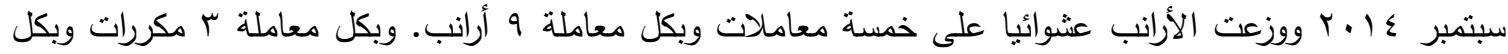

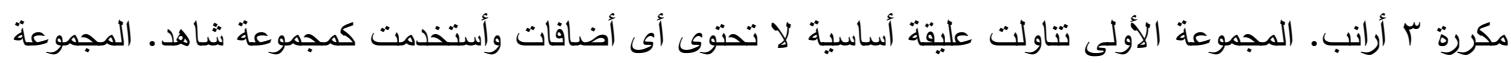

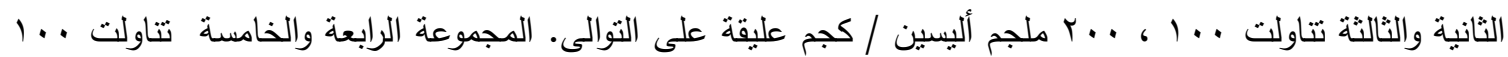

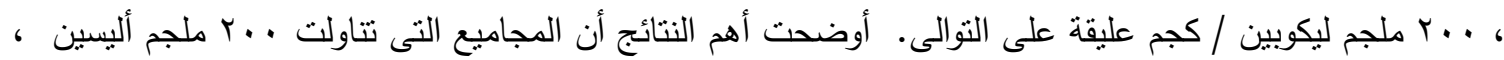

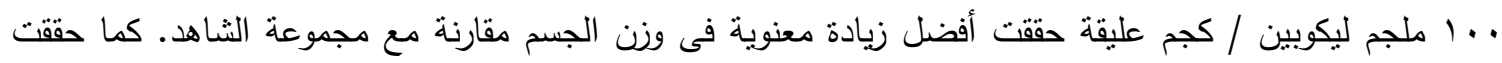
المجاميع الأخرى زيادة رقميه ولكن لم تكن معنوية. حدث تحسن معنوى فى الكفاءة التحويلية فى جميع المجاميع مئه

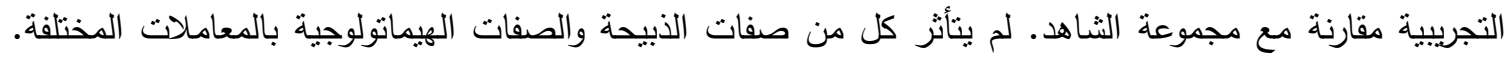

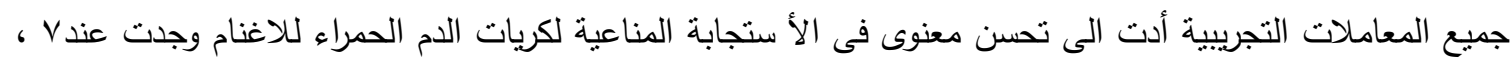

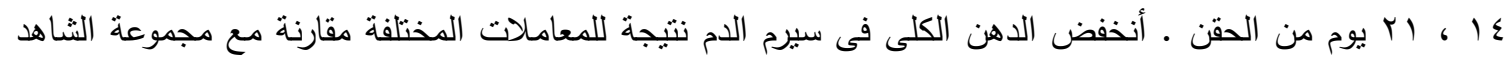

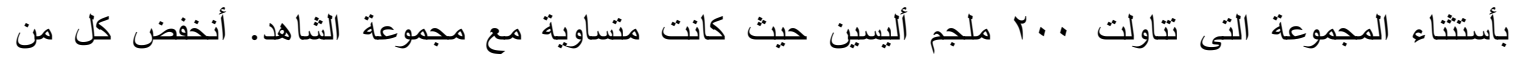
الكولسترول الكلى والدهون الثثلثية نتيجة لاضافة النسب المختلفة من الألبيسن والليكوبين مقارنة مع مجموعة الثاهد. تلاحظ أنخفاض رقمى فى الكولسترول منخفض الكثافة بينما تلاحظ أرتفاع رقمى فى الكولسترول مرتفع الكثافة والنسبة بين الكولسترول مرتفع الكثافة الى الكولسترول منخفض الكثافة نتيجة لجميع الاضافات المستخدمة ولكن هذه

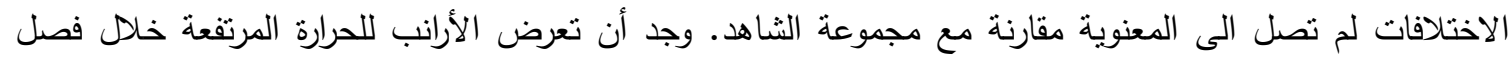

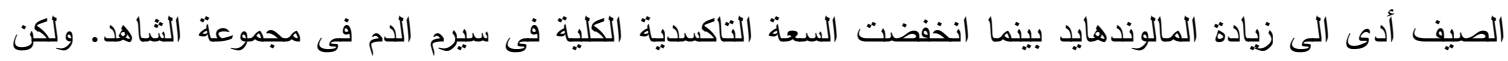

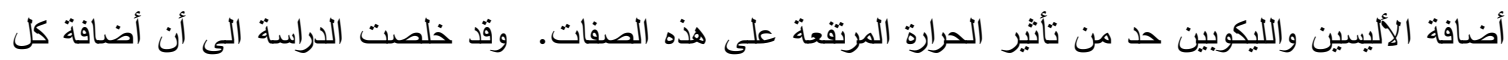

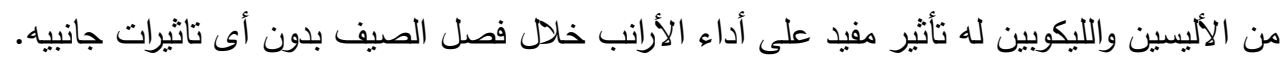

